\title{
“Likes" para a história no Instagram: algumas questões sobre história, ensino e representação
}

\author{
“Likes" for history on Instagram: some questions about history, \\ teaching and representation
}

\author{
“Likes” para la historia en el Instagram: algunas cuestiones sobre \\ historia, enseñanza y representación
}

Erinaldo Cavalcanti 1

https://orcid.org/0000-0002-9912-57/3

\begin{abstract}
Resumo: $O$ artigo problematiza um conjunto de 21 imagens publicadas na rede social Instagram no dia 19 de agosto - Dia do Historiador - para analisar algumas representações circuladas acerca da História nas referidas postagens. Como procedimento metodológico, as imagens foram selecionadas de forma aleatória no dia 19 de agosto de 2020 através dos perfis seguidos pelo laboratório e grupo de pesquisa Interpretação do Tempo: ensino, memória, narrativa e política (iTemnpo) por meio de sua conta @itemnpo. Em seguida as imagens foram categorizadas em três tipologias: a) "autoria do conteúdo postado" b) "tipologia do perfil" e c) "referencialidade". Pelas postagens analisadas se percebe uma representação da História voltada apenas para sua dimensão acadêmica, sendo apresentada predominantemente por imagens de pesquisadores masculinos, europeus e sem relação com o ensino de História.
\end{abstract}

Palavras-chave: História. Representação. Redes sociais. Ensino de História.

Abstract: The article discusses a set of 21 images published on the social network Instagram on August 19th Historian's Day - to analyze some representations circulated about History in the posts. In the methodological procedure, the images were selected at random on August 19, 2020 using the profiles followed by the laboratory and research group (iTemnpo) through its account @itemnpo. Then the images were categorized into three types: a) "authorship of the posted content" b) "profile typology" and c) "referentiality". Through the analyzed posts, it is possible to perceive a representation of History focused only on its academic dimension, being presented predominantly by images of male, European researchers and unrelated to the History teaching.

Keywords: History. Representation. Social networks. History teaching.

Resumen: El artículo analiza un conjunto de 21 imágenes publicadas en la red social Instagram el 19 de agosto - Día del Historiador - para analizar algunas representaciones circuladas sobre la Historia en las publicaciones mencionadas. Como procedimiento metodológico, las imágenes fueron elegidas espontáneamente el 19 de agosto de 2020 a través de los perfiles seguidos por el laboratorio y grupo de investigación Interpretação do Tempo: ensino, memoria, narrativa e política (iTemnpo) a través de su cuenta @itemnpo. Luego, las imágenes se categorizaron en tres tipos: a) "autoría del contenido publicado" b) "tipología de perfil" y c) "referencialidad". A

\footnotetext{
' Doutor em História pela UFPE. Professor permanente e coordenador do Programa de Pós-graduação em História da Universidade Federal do Sul e Sudeste do Pará (Unifesspa). E-mail: ericontadordehistorias@gmail.com
}

Olhar de professor, Ponta Grossa, v. 24, p. I-19, e-17095.042, 2021.

Disponível em <https://revistas2.uepg.br/index.php/olhardeprofessor> 
través de los posts analizados, es posible percibir una representación de la Historia centrada únicamente en su dimensión académica, siendo presentada predominantemente por imágenes de investigadores masculinos, europeos y ajenas a la enseñanza de la Historia.

Palabras-clave: Historia. Representación. Redes sociales. Enseñanza de la Historia.

\section{Introdução}

A primeira sentença do título tem uma dosagem de provocação. O termo like é de origem inglesa e, em uma tradução literal, significa "gostar". Nas redes sociais, like também significa "curtir", "gostar", "estar de acordo", "aprovar”. Essa expressão tem se popularizado entre os falantes de língua portuguesa, em terras chamadas Brasil, pelo uso intenso nesses espaços digitais. Receber curtidas (ou likes), nas postagens, era - e é - sinônimo de prestígio e, até, de influência. Esses indicadores eram - e são - acionados, inclusive, pelo número de curtidas recebidas, sempre à mostra de todos. Quando a rede social Instagram decidiu parar de mostrar os números de likes nas postagens, foi até criticada por representantes dos legislativos espalhados pelo Brasil2.

Publicar em uma rede social é fazer uma postagem, também chamada de post. Quem faz uma postagem deseja que ela seja vista, circulada, discutida. Via de regra, espera-se receber likes, ou seja, curtidas.

Este texto não tem por objetivo fazer uma incursão sobre as imagens publicadas acerca da História e suas repercussões, reproduções, números de curtidas e formas de apropriação. Seguir essas questões demandaria uma pesquisa muito mais ampla e tempo para sua execução, o que ultrapassaria os limites de um artigo. $O$ foco da reflexão aqui colocada foi refletir sobre quais postagens são publicadas sobre a História - na data em que se comemora o dia do(a) historiador(a) - capazes de mobilizar likes entre os seguidores dos perfis nessas redes sociais. Que representação contêm esses posts?

O presente texto faz parte do meu percurso de reflexão que tem o Ensino de História como campo privilegiado de problematização. Como lugar de saber/poder, trata-se de um espaço disputado por diferentes forças e distintas narrativas. Nesse campo, tenho priorizado, como locus de estudo, questões que envolvem o ensino de História e os livros didático, o lugar ocupado pelo debate sobre o ensino e o livro didático e a formação docente nos desenhos curriculares da formação inicial dos professores.

A minha imersão nesse campo, após o convite para escrever um livro didático de História para crianças, permitiu-me redimensionar minha relação com a ciência, dita de referência. De tal modo, fui

2 “Carlos Bolsonaro reclama de mudança no Instagram: 'Cartilha ideológica progressista”. Istoé, I7/07/2019. Disponível em: <https://istoe.com.br/carlos-bolsonaro-reclama-de-mudanca-no-instagram-cartilha-ideologicaprogressista/> 
impelido a repensar as relações entre o que produzimos na academia e as demandas reais de homens e mulheres que não fazem parte desse mundo acadêmico, quase sempre encastelado. Assim, ia percebendo que nessa ciência - História - somos instrumentalizados a dar conta de um conjunto de demandas predominantemente voltado aos interesses da própria academia. Essa instrumentalização pouco nos habilita a dialogar com quem não habita o castelo. Dito de outra maneira, não aprendemos a narrar para quem não é historiador. Talvez, a escolha da História - como ciência - em priorizar apenas as demandas teórico-metodológicas no processo pelo qual se constituiu ciência, tenha sua responsabilidade. Essa escolha relegou algumas questões (como o ensino da própria da área e/ou a aprendizagem histórica) a um papel de menor importância, ou até mesmo desinteressante para a ciência histórica, como ressalta Jörn Rüsen (20I5).

O acesso às redes sociais tem impacto a ciência histórica e deve ser objeto de interesse da teoria da História como ressalta Jörn Rüsen (2015). Essa prática é cada vez mais presente no nosso cotidiano. O consumo das informações postadas faz parte do dia a dia de milhões de pessoas incluindo professores e alunos de diferentes faixas etárias. No que diz respeito à História e seu ensino na relação com o mundo virtualizado são interessantes as reflexões de Bruno Leal Pastor de Carvalho (2014) ao analisar algumas relações entre e historiador as redes sociais. Também são interessantes as reflexões desenvolvidas por Dulci Tereza Spyer e Tarcísio Moreira (2019) sobre de três canais do YouTube voltados para o ensino de história.

Desse lugar, marcado pela polissemia de percepção, pela diversidade de interpretações e de dissensos e atravessado pelas relações do mundo virtual, escrevo este texto. Nele, problematizo algumas representações acerca da História, analisando um conjunto de 21 imagens postadas e circuladas nas redes sociais nos dias imediatos ao 19 de agosto de 2020 , em alusão ao dia do historiador. A partir das imagens selecionadas, analiso, também, quem são as referências mobilizadas, algumas ideias representadas e o lugar do ensino de História nas imagens circuladas.

\section{Corpus documental e procedimentos metodológicos}

O laboratório e grupo de pesquisa iTemnpo tem uma conta na rede social Instagram ${ }^{3}$ com o endereço@itemnpo. Atualmente, o perfil do laboratório conta com, aproximadamente, 10 mil seguidores, e segue quase cinco mil perfis ${ }^{4}$. As imagens aqui analisadas foram selecionas de forma

\footnotetext{
${ }^{3}$ Instagram é uma rede social online voltada, predominantemente, para o compartilhamento de fotos e vídeos entre seus usuários. Pertence à empresa Facebook que tem como diretor geral — também chamado de "CEO" — o estadunidense Mark Elliot Zuckerberg. O Brasil é o terceiro no ranking do número de usuários do Instagram, perdendo apenas para os Estados Unidos e a Índia. Atualmente, o País conta com 69 milhões de usuários, praticamente o dobro do que tinha em 2017, segundo o site de notícias Apptuts.net.

${ }^{4}$ É importante registar que esses dados são bastante móveis e podem mudar de forma muito rápida.
}

Olhar de professor, Ponta Grossa, v. 24, p. I-19, e-17095.042, 2021.

Disponível em <https://revistas2.uepg.br/index.php/olhardeprofessor> 
“Likes" para a história no Instagram: algumas questões sobre história, ensino e representação

aleatória dos perfis seguidos pelo @itemnpo 5 . Para fins de registro e análise, a seleção das imagens ocorreu no dia 19 de agosto de 2020 , data em que se comemora o dia do historiador ${ }^{6}$. À medida que eu acessava o perfil da conta e havia postagem dos seguidores sobre "o dia do historiador", ia fazendo o registro da referida postagem.

O passo seguinte foi criar uma pasta no computador para salvar as postagens selecionadas. Depois, passei a categorizar as imagens pelos autores dos enunciados apropriados e divulgados na rede, mobilizando a categoria de "autoria do conteúdo postado". Aqui, a autoria acionada para essa estratificação não foi a da postagem na conta do Instagram, uma vez que o(a) administrador(a) do perfil, ao fazer uma postagem, em alguma medida acaba ocupando o lugar de autoria do material postado. Todavia, para a análise das imagens, utilizei a autoria do conteúdo expresso nas postagens, ou seja, a qual autor(a) pertencem as frases usadas e publicadas.

Outra categoria que defini para analisar as imagens foi a "tipologia do perfil" das contas do Instagram para registrar se as imagens publicadas pertenciam a uma conta pessoal/particular ou "institucional", de grupo de pesquisa, associação, programa de pós-graduação, faculdade ou revista acadêmica. Por fim, criei outro agrupamento para as imagens que denominei de "referencialidade". Para essa categoria, identifiquei a vinculação teórica dos(as) autores(as) citados(as) nas postagens, registrando a aproximação com a concepção de História representada pelas referências usadas. Também foi possível, dentro dessa categoria, refletir sobre o lugar social ao qual pertencem os autores citados e o lugar ocupado pelo ensino nas representações publicadas nas postagens analisadas.

Após a seleção do conjunto das imagens, percebi que era necessário criar outra categoria para algumas postagens que não se enquadravam em nenhuma das expostas até aqui. Para essa demanda, criei a categoria "outras", para a qual separei postagens que contribuíam para dinamizar as representações sobre a História, mas não se enquadravam nas categorizações mobilizadas. Ainda como opção metodológica, para a escrita deste artigo, gostaria de explicar que o diálogo com alguns autores aparecerá ao longo do texto, e não em um subtítulo específico.

\footnotetext{
${ }^{5}$ Sabemos que as postagens que aparecem no feed de notícia não ocorrem de forma aleatória. Há tecnologia que seleciona o tipo de postagem que visualizamos a partir do perfil da conta na rede social. De tal modo, as imagens selecionadas, aqui, também já são fruto dessa seleção.

${ }^{6}$ A Lei $n^{\circ}$ 12.130, de 2009, criou oficialmente o dia do historiador. O dia 19 de agosto foi escolhido em homenagem ao nascimento de Joaquim Nabuco (19 de agosto de 1849). $O$ homenageado foi um dos fundadores da Academia Brasileira de Letras, intelectual envolvido com o movimento abolicionista e exerceu a função de diplomata, jurista e jornalista, além de político. Faleceu em janeiro de 1910.
} 


\section{A história representada nas postagens analisadas}

Inicialmente, é necessário destacar que as postagens usadas oferecem variadas possibilidades de leituras e que as que apresento aqui não esgotam as reflexões. Trata-se de um olhar guiado por um ângulo de perspectiva diante de um caleidoscópico de interpretações. Nesse sentido, a primeira reflexão aqui colocada é direcionada para identificar quais foram os autores - ou autoras escolhidos para "dar likes” para a História. Ou seja, que personagens foram mobilizados para representar a História no dia em que se comemorava o Dia do Historiador. O Gráfico I mostra a estratificação da primeira categoria anteriormente mencionada.

Gráfico I - Relação dos(as) autores(as) citados(as) nas postagens

\section{Quantidade de postagens por autor/a}
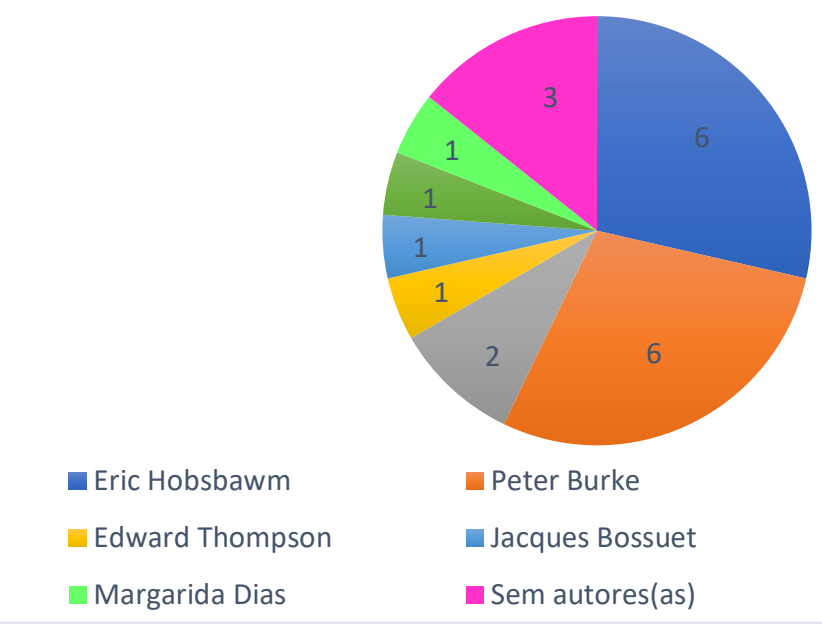

- Peter Burke

Marc Bloch

- Jacques Bossuet

- Georges Didi-Huberman

- Sem autores(as)

Fonte: elaborado pelo autor, 2020.

Essa primeira amostragem já nos permite muitas reflexões. Nela, percebemos quem são os autores acionados para representar a História. É claro que precisamos repetir, aqui, o minúsculo universo que compõe a análise neste texto. Apenas 21 postagens. Todavia, ela apresenta uma pequena síntese acerca de algumas autoridades intelectuais que ocupam o lugar de referência sobre a História como ciência. Desse lugar de autoridade, os nomes citados, em alguma medida, desejam reforçar a importância da data comemorada por meio das postagens com as referidas citações. Em outras palavras, são nomes que, entre os seguidores nas redes sociais, têm a capacidade de fomentar as curtidas ou receber likes para a História.

Eric Hobsbawm e Peter Burke têm seis postagens cada um. Todavia, sobre o autor de A era dos extremos, são usadas três citações distintas, que também são publicadas em diferentes perfis, apenas mudando a configuração em termo de layout da postagem. A frase de Peter Burke, por sua vez, 

é a mesma usada em todas os posts. Vejamos, na Figura I, as postagens com mais recorrência que compõem a amostragem.

Figura I: Postagens com referência atribuída a Eric Hobsbawm

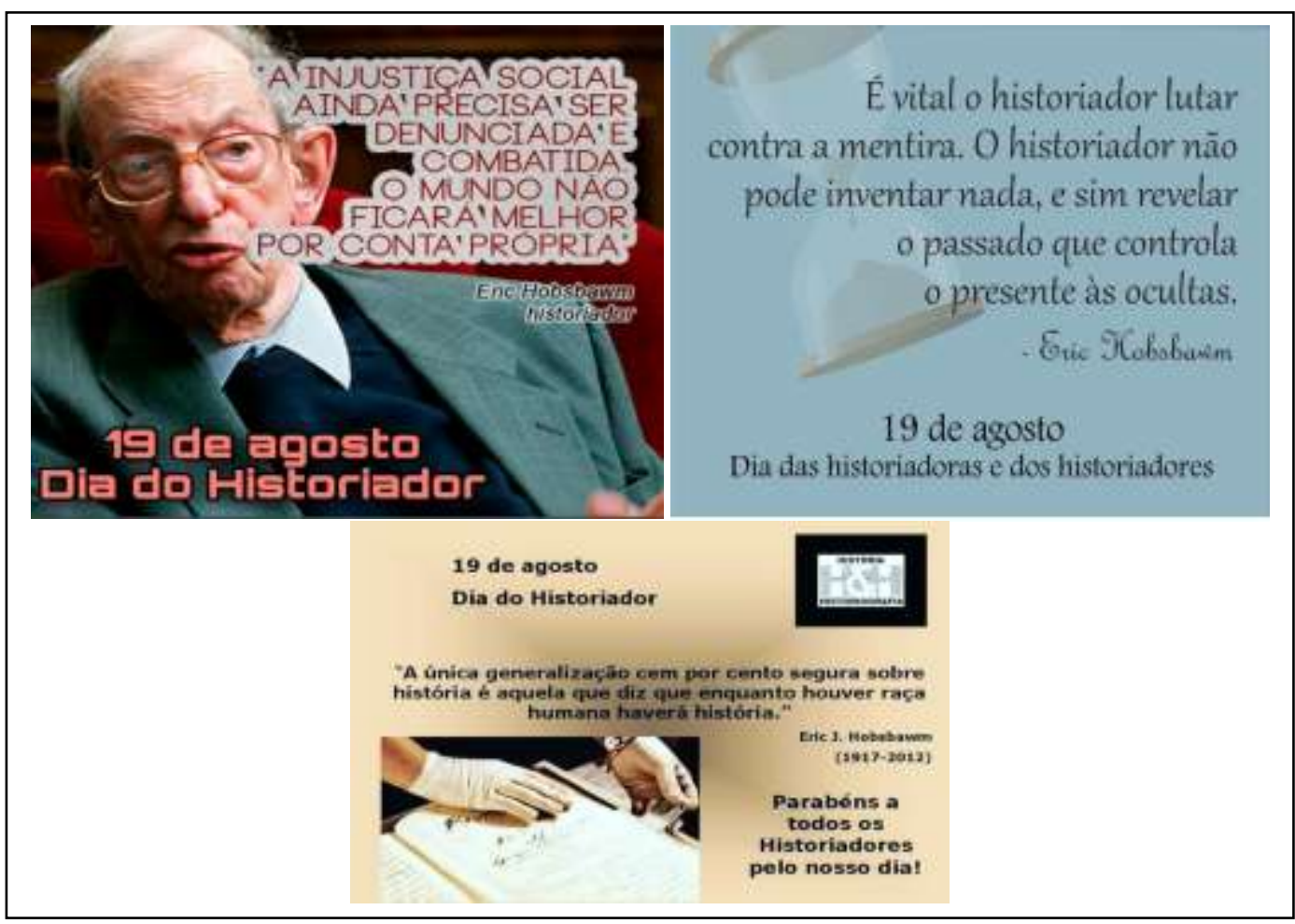

Fonte: elaborada pelo autor, 2020.

Não há espaço suficiente, pelos limites de um capítulo, para fazer uma análise detalhada de cada imagem. Também esse não é o objetivo de reflexão. Mas, a materialidade, os ícones utilizados e os tipos de letra, cor e fonte são elementos que formam as postagens com as citações mobilizadas, incluindo o recurso da própria imagem do autor citado. Em alguma medida, esses elementos contribuem para produzir efeitos de sentido e de verdade aos objetivos almejados por aqueles e aquelas responsáveis pelas postagens. A forma, como ressalta Roger Chartier (2003), produz efeito, tem sentido e implica uma percepção e leitura de seus autores. Ou seja, a forma não é neutra nem desprovida de significado. Ainda, inspirado nas reflexões de Roger Chartier (201 I), a representação é apreendida, aqui, como um conjunto variado de elementos e práticas capazes de fazer ver algo ou alguma coisa ausente, e que concorre como uma das forças constituidoras do mundo social. Como defende o autor, "[...] não existe história possível se não se articulam as representações das práticas e as práticas da representação". (CHARTIER, 20II, p. 16). Suas análises chamam a atenção para a relação entre as fontes documentais e as práticas por elas representadas, não existindo relação de complementariedade e transparência entre essas dimensões. 
Peter Burke também teve seis postagens com citação cuja autoria lhe era atribuída. Com diferentes layouts, os posts registrados fizeram uso da citação exposta na imagem apresentada na Figura 2.

Figura 2: Postagem com a citação atribuída a Peter Burke.

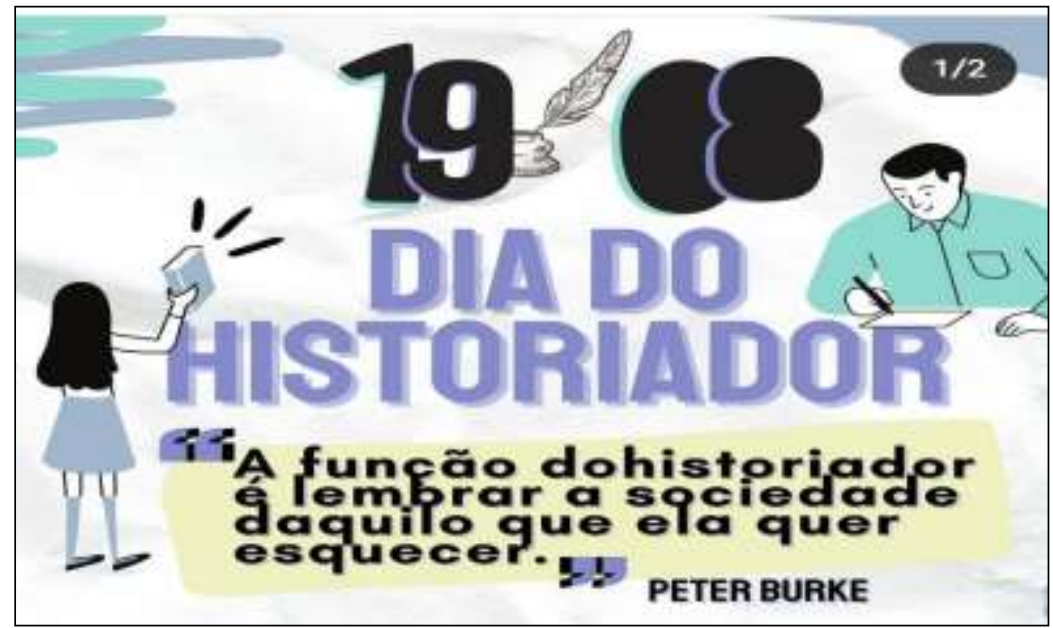

Fonte: elaborada pelo autor, 2020

A citação atribuída a Peter Burke disputa o centro da imagem com a informação da data celebrada.Todavia, um conjunto de elementos gráficos também foi acionado. Uma pena em um tinteiro, um livro na mão de uma menina e um homem escrevendo. Símbolos que representam tempos, atividades e práticas variadas que concorrem para formar um conjunto diverso de atividades desempenhadas pelo profissional homenageado.

Além de Eric Hobsbawm e Peter Burke, também registrei imagens com citação de mais três autores e uma autora. Como mostrado no Gráfico I, também identifiquei postagens com citação de Marc Bloch, Edward Thompson, Jacques Bossuet, Georges Didi-Huberman e Margarida Dias.

Nesse conjunto de registro, podemos perceber que as referências usadas nas citações são, predominantemente, de homens. Esse é um primeiro corte a ser ressaltado. A autoria das citações é atribuída a homens. A exceção reside na postagem publicada pelo Grupo de Trabalho em Ensino de História do Rio Grande Norte ao citar um trecho da tese de doutorado da professora Margarida Dias de Oliveira. Pelo conjunto das postagens, podemos afirmar que as representações constatadas ainda têm a figura do masculino como a referência identificadora da História. Apesar do diminuto corpus documental analisado neste texto, essa representação da História com o masculino não é desprovida de sentido. Tampouco se restringe às imagens circuladas nos perfis de Instagram e apropriadas nesta reflexão.

É oportuno destacar que os registros com esses nomes identificados não podem ser apreendidos como se fossem as únicas ou principais referências representativas da concepção de 
“Likes” para a história no Instagram: algumas questões sobre história, ensino e representação

História circulada nas redes sociais, nem mesmo no Instagram. Além de trabalharmos com uma amostragem pequena $-2 \mathrm{I}$ perfis dos quais registrei as imagens - a escolha dos autores citados nas postagens certamente está vinculada às experiências formativas das pessoas responsáveis pelas publicações. Portanto, estamos lidando com um pequeno estrato de um amplo mosaico representativo da História. Os registros aqui analisados são uma gota de água de um imenso oceano de imagens que compõem uma multiplicidade de representações acerca da História. Mas, como nenhuma generalização tem fundamento na análise da ciência histórica, vamos, sim, continuar analisando uma gota de água por entendermos que essa pequena partícula é parte constituinte do oceano.

\section{Quais são os perfis das imagens sobre a história?}

Sabemos que toda forma de enunciado mostra não apenas o conteúdo de uma prática discursiva, mas também seu lugar de enunciação. Entender esse lugar permite compreender as formas de enunciação, o conteúdo e as suas representações. Por isso, irei mostrar, rapidamente, quais foram os perfis que publicaram as imagens aqui analisadas.

Por uma questão de ética e privacidade, não mostrarei os nomes das contas pessoais, mesmo não fazendo nenhuma crítica aos(às) administradores(as). Mas, para mencioná-los nominalmente, seria apropriado solicitar sua autorização, a fim de manter as boas práticas e o respeito necessários.

Entre os perfis que não são pessoais, registrei imagens das seguintes contas: Associação Nacional de História (ANPUH)-PE, ANPUH-AP, ANPUH-RJ, Revista Em Tempos de História, Grupo de Pesquisa Ensinar História, Núcleo de Estudos sobre Biografia, História, Ensino e Subjetividade (NUBHES-UERJ), Verbalizando História, GT Ensino de História, RN, Laboratório de Aprendizagem e Ensino de História (LAEH-UPFE) e Centro Universitário Uni-Ages. Os demais perfis são de estudantes e professores(as) de História com nível de formação entre graduados(as) e doutores(as).

Também é necessário registrar que as postagens circuladas nos perfis de grupos de pesquisas, associações, revistas e centros de pesquisas não podem ser apropriadas como se representassem "a" concepção que esses lugares têm sobre a História. Esses espaços são plurais, compostos por diferentes professores(as) pesquisadores(as) e seria arriscado apreender uma imagem como algo capaz de representar a diversidade de percepções dos seus membros. Mesmo que essas postagens tenham sido publicadas nesses perfis, é necessário levar em consideração que elas podem estar mais próximas da pessoa responsável pela postagem naquele momento; ou seja, daquele ou daquela que se encontra como "administrador" do perfil.

É importante ressaltar que entre as postagens analisadas não identifiquei a vinculação de um autor citado a um tipo de perfil (pessoal ou institucional). Dessa forma, percebe-se que as referências acionadas, por exemplo, são compartilhadas tanto por aqueles perfis de associação acadêmica como 
pelos perfis pessoais. Eric Hobsbawm e Peter Burke são citados nos dois tipos de perfis. Esse dado também é identificado entre os perfis pessoais. Ou seja, tanto nas contas de estudantes como nas de professores já formados, e com diferentes níveis de titulação, encontramos essas referências sendo acionadas. Essa constatação sugere, pois, que os autores mobilizados nas postagens publicadas transitam entre diferentes profissionais da área da História com diferentes titulações. Mas é oportuno destacar, também, os outros autores catalogados na amostra, como Edward Thompson, no perfil da Revista da UnB, e Georges Didi-Huberman, Jacques Bossuet e Marc Bloch, em perfis pessoais.

Ainda sobre a tipologia dos perfis, é importante registar as instituições às quais pertencem ou nas quais se formaram os profissionais donos das contas, cujas postagens são aqui analisadas. A começar pela ANPUH-Brasil. Suas filiais, sediadas nos estados, publicaram diferentes postagens no dia 19 de agosto. Mas, vamos nos concentrar naquelas que foram registradas para a presente análise. De tal modo, temos os registros da ANPUH das sessões do Rio de Janeiro, de Pernambuco e do Amapá. As sessões do Amapá e do Rio de Janeiro fizeram uso da mesma citação de Eric Hobsbawm. O que difere é apenas o layout da postagem, mas o conteúdo é o mesmo. Temos, ainda, os laboratórios ou grupos de trabalhos vinculados à Universidade Federal de Pernambuco (UFPE), à Universidade Federal do Rio Grande do Norte (UFRN) e à Revista Em Tempos de História, vinculada ao Programa de Pós-Graduação da Universidade de Brasília (UnB). Também percebemos essa diversidade de instituições nos perfis pessoais, ao menos naqueles que têm essa informação registrada. Para essa tipologia, temos entre estudantes e professores formados nas seguintes instituições: UFPE, UFRN, Universidade Federal da Paraíba (UFPB) e Universidade de Pernambuco (UPE).

\section{“Qual história” representam as referencialidades citadas?}

Para sabermos por quais motivos os perfis selecionaram as imagens postadas, teríamos que escrever a cada um solicitando uma resposta. Mesmo assim, talvez, teríamos explicações que fugiriam dos propósitos de reflexão deste texto. É possível, todavia, analisar os nomes citados e suas filiações teóricas, as possíveis concepções de História que defenderam ou defendem, o lugar social das autorias mobilizadas e o conteúdo propriamente citado.

Uma primeira interpretação acerca dos nomes mobilizados nas postagens mostra uma diversidade de autores vinculados a diferentes "alinhamentos" teóricos. É demasiado complexo vincular autores a correntes teóricas e/ou epistemológicas. Bem sabemos que essas denominações e classificações, muitas vezes, servem como espaços de disputas para marcar posição e ocupar certos lugares nas relações de poder constituintes dos campos acadêmicos. Ademais, não raro se percebe como essas vinculações autor/teoria são atribuições de sentidos que enquadram e engessam algumas representações sobre pessoas e ideias. Nesses termos, a identificação e/ou aproximação entre autor e 
“Likes" para a história no Instagram: algumas questões sobre história, ensino e representação corrente teórico-epistemológica precisa ser operada de forma maleável, fluida e porosa, no sentido de que um mesmo autor pode transitar por esses espaços estabelecendo diálogos e trocas.

Dito isso, pode-se proceder com algumas aproximações entre os nomes dos autores citados nas postagens. Entre aqueles que mais publicações tiveram, percebemos um nome geralmente associado à chamada história marxista, e outro, à história cultural: os britânicos Eric Hobsbawm e Peter Burke, respectivamente. Trata-se de dois intelectuais que desfrutam de importante lugar de reconhecimento entre as referências indicadas para os cursos de História no Brasil.

Mas, outros nomes também aparecem entre as referências acionadas sobre a História. Edward Thompson, Marc Bloch, Jacques Bossuet, Georges Didi-Huberman e Margarida Dias. Pelos nomes - e correndo todos os riscos de simplificações - pode-se dizer que teríamos um historiador vinculado à chamada História social inglesa. Da França, três nomes com formações e lugares distintos: Marc Bloch, vinculado à história do Annales; Didi-Huberman, historiador e filósofo crítico da arte, e o intelectual e teólogo Jacques Bossuet, contemporâneo e teórico do absolutismo. Do Brasil, temos o nome de Margarida Dias, professora e pesquisadora ligada ao campo do Ensino de História.

A pluralidade dos autores mostra a diversidade de referências mobilizada. Diante do mosaico de nomes registrados nas postagens, temos um ponto em comum. Com exceção do nome da professora da UFRN, são todos homens pertencentes à Europa. Assim, não seria inverossímil dizer que a referencialidade buscada nos nomes postados no dia do Historiador continua sempre aquela do velho continente. Ou seja, ainda é a Europa o lugar de referência, onde se buscam os nomes das autoridades que representam, em alguma medida, essa ciência.

Não é nosso objetivo - nem temos espaço nos limites de um capítulo — estender a reflexão sobre a predominância do eurocentrismo na ciência histórica praticada no Brasil.Todavia, é importante registar como ainda permanecemos ligados, umbilicalmente, às referências europeias, inglesas e francesas. Essa configuração contribui para a gestação de um modelo de formação docente inicial calcado nos marcos temporais da História quadripartite. Nos percursos formativos, os Projetos Políticos Pedagógicos dos cursos de licenciatura em História, no Brasil, elaboram as disciplinas tendo a História europeia como referencialidade, tanto na definição das disciplinas obrigatórias como na distribuição dos componentes, no sequenciamento e nas referências indicadas nas bibliografias básicas (CAVALCANTI, 2020).

Continuemos o percurso pela análise das postagens. Os nomes usados são de autores que têm vasta bibliografia, que desfrutam de uma reconhecida produção intelectual. O Quadro 2 mostra os(as) autores(as) citados e suas respectivas citações.

Olhar de professor, Ponta Grossa, v. 24, p. I-19, e-17095.042, 2021.

Disponível em <https://revistas2.uepg.br/index.php/olhardeprofessor> 
Quadro 2: Relação autor/citação

\begin{tabular}{|c|c|}
\hline & Transcrições das citações postadas \\
\hline Autores(as) & Citação postada \\
\hline \multirow{3}{*}{ Eric Hobsbawm. } & $\begin{array}{l}\text { É vital o historiador lutar contra a mentira. O historiador não pode inventar } \\
\text { nada, mas sim revelar o passado que controla o presente às ocultas. }\end{array}$ \\
\hline & $\begin{array}{l}\text { A única generalização cem por cento segura sobre a história, é aquela que diz } \\
\text { que enquanto houver raça humana haverá história }\end{array}$ \\
\hline & $\begin{array}{l}\text { A injustiça social ainda precisa ser denunciada e combatida. O mundo não ficará } \\
\text { melhor por conta própria. }\end{array}$ \\
\hline Peter Burke. & A função do historiador é lembrar a sociedade daquilo que ela quer esquecer. \\
\hline Marc Bloch. & A ignorância do presente nasce fatalmente da incompreensão do passado \\
\hline Edward Thompson. & $\begin{array}{l}\text { Um historiador deve estar decididamente interessado, muito além do } \\
\text { permitido pelos teleologistas, na qualidade de vida, nos sofrimentos e } \\
\text { satisfações daqueles que vivem e morrem em tempo não redimido. }\end{array}$ \\
\hline Jacques Bossuet. & $\begin{array}{l}\text { A história é o grande espelho da vida; instrui com a experiência e corrige com } \\
\text { o exemplo. }\end{array}$ \\
\hline $\begin{array}{l}\text { Georges } \\
\text { Huberman. }\end{array}$ & $\begin{array}{l}\text { A pedagogia da história é, antes de mais nada, compreender que uma coisa } \\
\text { passou e no entanto não passa (isto é, continua travada em nossas gargantas e } \\
\text { em atuar em nossos espíritos). É aprender a saber o que é passado, como isso } \\
\text { passou e em que medida se passou em nós e aí ficou travado. Para isso, é preciso } \\
\text { aprender a olhar os vestígios, ler os arquivos e escavar o solo do tempo. }\end{array}$ \\
\hline Margarida Dias. & $\begin{array}{l}\text { O debate sobre o direito ao passado, a ser feito pelos historiadores, torna-se, } \\
\text { assim, mais importante, porque ele definirá não só sua formação, mas o que, } \\
\text { do ponto de vista do conhecimento histórico, em cada etapa, é essencial que } \\
\text { o aluno-cidadão aprenda. }\end{array}$ \\
\hline
\end{tabular}

Fonte: elaborado pelo autor, 2020.

Seria imprudência de minha parte fazer inferências sobre o pensamento de um(a) autor(a) a partir de uma frase. Mas, o objetivo da reflexão é analisar a ideia de História e de historiador(a) a partir das postagens publicadas. Assim sendo, é possível destacar algumas representações fragmentárias e parciais nas citações. Do inglês Eric Hobsbawm, é possível perceber a ideia de História como uma produção ligada e comprometida com a verdade. E, para isso, caberia a essa ciência a função de apresentar, de forma fiel, o passado, expressa pelo uso do verbo "revelar" empregado na oração. A citação seguinte representa a História como um conhecimento particular, específico, no qual não cabe nenhum tipo de generalização. Por último, percebe-se uma vinculação entre a História e a luta contra as desigualdades sociais. Assim, o conhecimento histórico teria, também, um caráter de denúncia em prol da justiça social.

Na citação atribuída a Peter Burke, a História é vista como um conhecimento, cuja função principal é lutar contra a ação corrosiva do esquecimento. Assim, a História teria o dever de impedir que a sociedade esqueça e apague, por extensão, suas próprias experiências. Seria, portanto, um conhecimento que garantiria a manutenção, no presente, de um conjunto de informações sobre as experiências passadas, como forma de manter sempre presentes os 
“Likes" para a história no Instagram: algumas questões sobre história, ensino e representação

relatos do passado. Marc Bloch é chamado nas citações por meio de uma sentença na qual relaciona e conecta os tempos passado e presente. De tal modo, a História seria essa ciência capaz de produzir um conhecimento que permite compreender o presente por meio do entendimento do passado. Edward Thompson, por sua vez, pela citação postada, relaciona a História e o historiador a um compromisso pela melhoria da vida, de modo que não sejam em vão as experiências vividas outrora, permeadas de sofrimentos ou mesmo da perda da própria vida. A História também é vista como aquela que ensina e permite corrigir erros com as experiências passadas. Essa é uma das representações possíveis na citação de Jacques Bossuet.

Georges Didi-Huberman é acionado em uma citação na qual destaca a complexidade dos tempos históricos. Nela, destaca que cabe à História compreender como os passados passam e não passam, ou seja, entender que os passados são também presentes. Para tanto, é necessário compreender e analisar os vestígios e saber interpretar os arquivos.

O conteúdo da última citação, aqui analisada, foi postado pelo Grupo de Trabalho em Ensino de História do Rio Grande do Norte. Trata-se de uma citação da tese da professora Margarida Dias de Oliveira, como mencionado anteriormente. Pelo trecho postado, a História como área de conhecimento está diretamente vinculada ao processo de construção político e social voltado à formação para a cidadania. De tal modo, o direito ao passado é indicado como uma condição para a formação do aluno-cidadão.

É oportuno destacar alguns elementos identificados nas postagens. Como já mencionado, entre as referências citadas é predominante a presença de autores masculinos. Todavia, as postagens não se resumem apenas à ideia transcrita em forma de frase com a autoria atribuída. Há outros elementos que compõem as postagens e que merecem uma breve reflexão. Trata-se de ícones, imagens, palavras, símbolos inseridos nas postagens além da ideia principal centrada na citação propriamente dita. Talvez residam, nesses elementos, algumas ideias que representam percepções dos(as) administradores(as) das contas sobre a História e/ou o(a) historiador(a).Vejamos alguns casos na Figura 3.

Olhar de professor, Ponta Grossa, v. 24, p. I-19, e-17095.042, 2021. 
Figura 3 - Exemplos de postagens que flexionam com o gênero feminino.

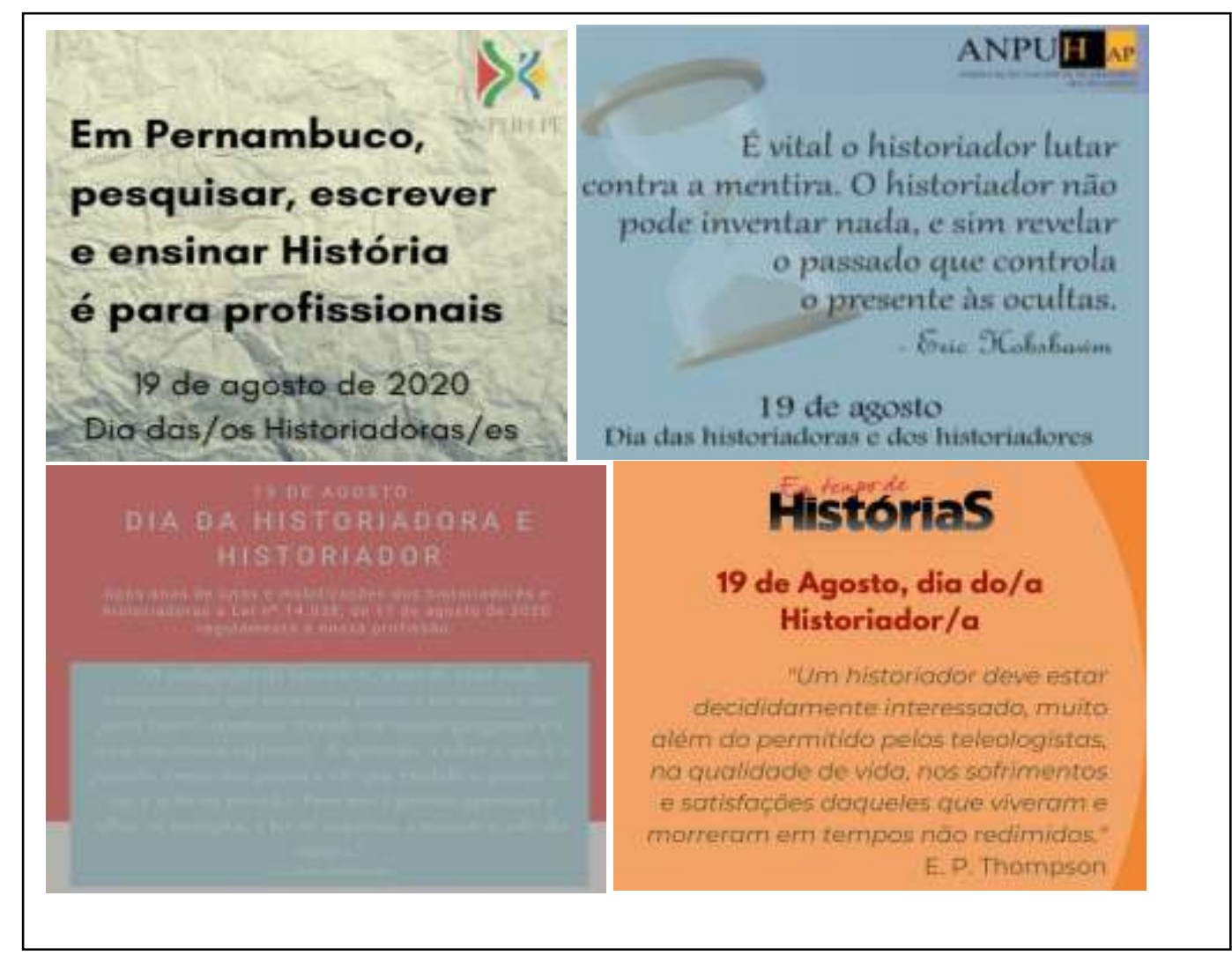

Fonte: elaboração própria, 2020.

O foco de reflexão, nessas imagens, não é direcionado para o conteúdo das frases dos autores acionados, mas no texto inserido pela pessoa responsável pela postagem. Mais precisamente, nos enunciados inseridos abaixo ou ao lado da mensagem principal. Nas quatro imagens, aqui mostradas, foram inseridos: "I 9 de agosto de 2020/Dia das(os) historiadoras(es)". Cabe o registro sobre como a semântica está flexionada com o gênero feminino. Nessas postagens, foi inserido o artigo feminino no plural ("as"), flexionando com o sujeito "historiadoras", o que mostra a inserção do gênero feminino entre aquelas que formam essa ciência.

Mesmo que não se perceba, na frase usada pela referência mobilizada, essa associação com o gênero feminino, a presenças das mulheres está nos elementos textuais colocados por aquelas e/ou aqueles que produziram a postagem. Ainda é interessante observar que, nas três primeiras imagens selecionadas, a flexão nominal primeiro aparece com o gênero feminino e, depois, com o gênero masculino: "1 9 de agosto de 2020. Dia das historiadoras e dos historiadores". Mas, essa inserção não esteve entre todas as 21 imagens analisadas neste texto. $\mathrm{O}$ Gráfico 2 mostra o resultado catalogado nas imagens. 
“Likes” para a história no Instagram: algumas questões sobre história, ensino e representação

Gráfico 2: Menção de gênero nas postagens analisadas

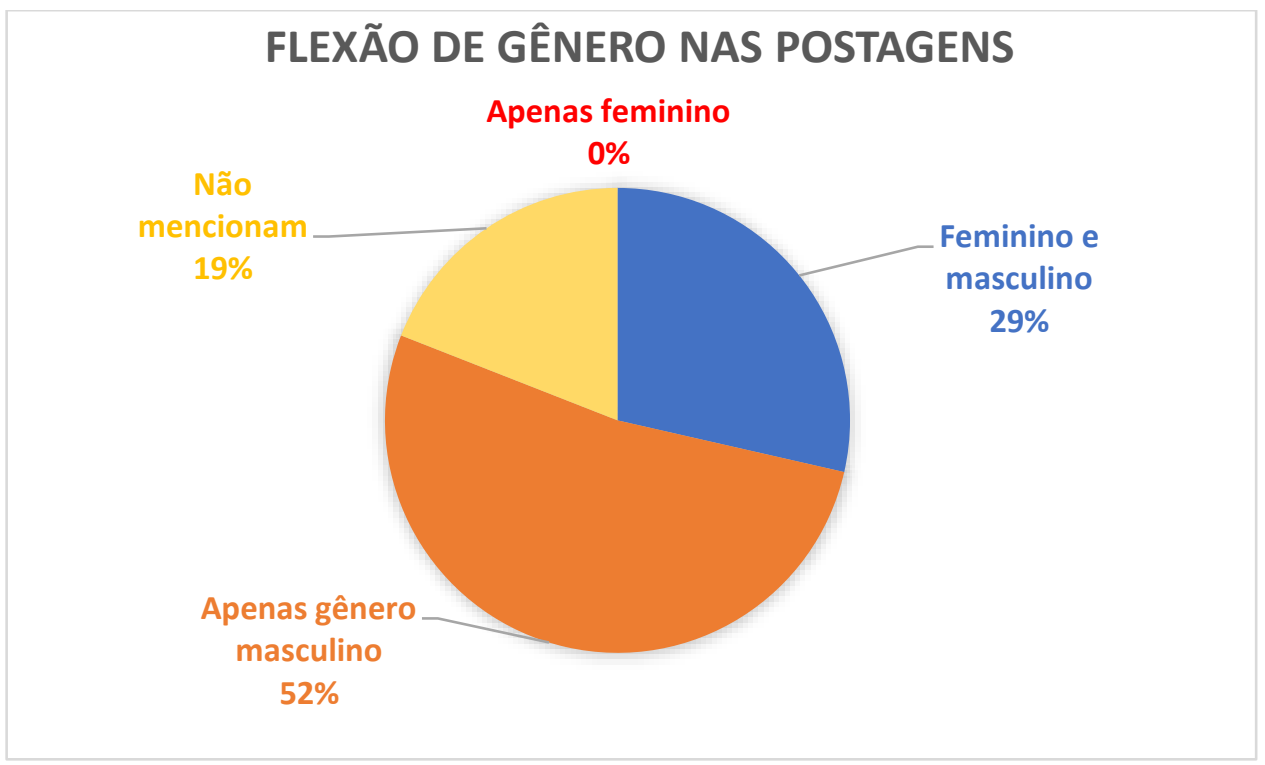

Fonte: elaborado pelo autor, 2020.

Como podemos perceber, ainda predomina, mesmo entre os elementos textuais inseridos pelas pessoas que fizeram as postagens, a presença do gênero masculino como o sujeito identificado e relacionado à História. No total, foram contabilizadas seis postagens que inseriram a flexão com o gênero feminino e masculino (29\%), I I apenas com o gênero masculino (52\%), quatro não inseriram nenhuma flexão (19\%) publicando a postagem com uma frase de um autor e nenhuma postagem foi identificada com a penas a flexão no feminino.

\section{O ensino é "algo" a ser lembrado no dia do(a) historiador(a)?}

Pelas expressões, frases, termos e ícones expressos nas postagens analisadas, percebe-se que a História ainda é associada ao gênero masculino. E sobre o ensino de História? O que as postagens, aqui mobilizadas, podem nos oferecer como indícios para a reflexão?

É oportuno ressaltar que não existe grafia inocente. Ao analisar as expressões presentes nas imagens - sejam aquelas contidas nas frases usadas como citação ou nos demais elementos inseridos pelas pessoas responsáveis pela postagem - a ausência do ensino é bastante perceptível.

Do universo de 21 postagens, apenas duas relacionaram a data do historiador ao ensino. Ou seja, 90,5\% dos posts publicados não relacionavam o dia do(a) historiador(a) ao ensino. Apenas duas postagens inserem questões ligadas ao ensino em suas publicações. São os posts publicados pela ANPUH-PE e pelo Grupo de Trabalho em Ensino de História do Rio Grande do Norte.

A ANPUH-PE escreveu, em sua postagem, "Em Pernambuco, pesquisar, escrever e ensinar história é para profissionais". A outra postagem publicou "O debate sobre o direito ao passado, a ser 
feito pelos historiadores, torna-se, assim, mais importante, porque ele definirá não só sua formação, mas o que, do ponto de vista do conhecimento histórico, em cada etapa, é essencial que o alunocidadão aprenda". Trata-se de uma citação extraída da tese da professora Margarida Dias de Oliveira. Na postagem da ANPUH-PE, percebemos a inserção da própria palavra "ensino" como uma das ações vinculadas à História e ao historiador. Na publicação do GT do Rio Grande do Norte, a vinculação se identifica na menção à formação do aluno.

Essa ausência identificada na maioria absoluta das postagens não é desprovida de sentidos. Ela indica que ainda continuamos a pensar (e a praticar?) a ciência histórica desvinculada da atividade do ensino; ou, ao menos, que o ensino continua ocupando um lugar de menor expressividade, e não se encontra entre aquelas atribuições que mereceriam ser expressas em uma homenagem na data em que se comemora o dia do(a) historiador(a).

É importante registrar que a ausência do ensino nas postagens analisadas não se limita apenas à falta de menção da palavra "ensino" nas publicações. Entre as 19 postagens, não aparece nenhum termo que estivesse relacionado ao ensino, não apenas nas citações usadas nos posts, mas também nos próprios ícones ou elementos inseridos no processo de produção das imagens. Dito de outra forma, as publicações analisadas sobre o dia do(a) historiador(a) não inserem nenhum elemento textual ou imagético que esteja relacionado ao mundo da escola, da sala de aula ou do aluno. Da mesma forma que os autores citados - com a exceção de uma das postagens - são referências da história, cujas contribuições não contemplam as problematizações acerca do ensino.

Entretanto, não podemos incorrer em generalizações apressadas e afirmar que, nas redes sociais, apenas circularam imagens que silenciam o lugar do ensino na História. Aqui, o corpus documental, como já mencionado, é bastante limitado em quantidade. Da mesma forma que é limitada a reflexão, pois se direciona apenas para analisar algumas representações identificadas nas postagens selecionadas. Esses limites se estendem, inclusive, pelo fato de que sabemos como acontecem algumas práticas ligadas à publicação de imagens nas redes sociais. Muitas vezes, acontece o simples ato de baixar uma imagem já "pronta" e replicar ou "republicar" em seguida. No entanto, não é objetivo desta reflexão analisar as razões que levaram os perfis selecionados a escolherem certas postagens com certas imagens. A partir do material publicado, buscou-se apresentar uma reflexão inicial, preliminar sobre quais imagens foram circuladas, quais ideias foram expressas, quais autores foram acionados para fazer referência à História e ao profissional dessa área.

Não podemos negar que as discussões sobre o ensino de História cresceram sobremaneira dentro dos departamentos e/ou faculdades de História no Brasil. Marieta de Moraes Ferreira (2016) analisou o crescimento das discussões sobre o ensino de História no âmbito da Pós-graduação no Brasil e apontou uma mudança significativa no lugar ocupado pelo ensino de História quando 
“Likes" para a história no Instagram: algumas questões sobre história, ensino e representação comparada com o cenário analisado em 2008 , conforme mostrou no texto em coautoria com Renato Franco (2008). De acordo com suas reflexões, o crescimento da pós-graduação e, de forma especial, a criação do mestrado profissional em rede, com área de concentração em ensino de História (ProfHistória), têm contribuído para alterar de forma propositiva os sentidos atribuídos e os significados construídos sobre o ensino de História. Com esse diagnóstico, a autora assinala que, atualmente, o ensino dessa disciplina encontra-se valorizado nos departamentos e/ou faculdades de História.

Seguindo esse movimento de reflexão, Ricardo Pacheco e Helenice Rocha (2016) pontuam o crescimento do número de linhas de pesquisa na pós-graduação em História sobre o ensino de História. Ao analisarem o cadastro dos programas de pós-graduação, alojados na Plataforma Sucupira, os autores mostram que, em 2015, dos 61 programas acadêmicos cadastrados, oito possuíam linha de pesquisa em ensino de História.

Não podemos negar que, nos últimos anos, ocorreram mudanças significativas envolvendo o lugar do ensino de História. Todavia, o crescimento das pesquisas na pós-graduação, certamente, leva algum tempo até chegar, como a própria formação inicial no nível de graduação.

Os silêncios identificados nas postagens analisadas não se limitam às representações veiculadas nas redes sociais. Nos percursos formativos dos cursos de licenciatura em História, nas universidades federais do Brasil, ainda persistem matrizes curriculares que definem uma carga horária reduzida ao debate sobre o ensino de História, ao livro didático e à aprendizagem histórica como mostram as pesquisas de Cavalcanti (2018, 2019 e 2020). Ainda se identificam muitas assimetrias entre as disciplinas obrigatórias sobre ensino de História, a formação docente e os demais componentes curriculares dos cursos de formação inicial como também mostram Mauro Cezar Coelho e Wilma de Nazaré Baía Coelho (2018) e Flávia Caimi (20I5).

Por esse ângulo de percepção, vale destacar as análises promovidas por Margarida Maria Dias de Oliveira. De acordo com a historiadora, a formação docente, como defendemos,

[...] só poderá ocorrer se houver reflexão acerca das referências de nossa área de conhecimento - a História. Assim não são algumas disciplinas de teoria e metodologia ou didáticas específicas para a História que irão garantir a formação de profissionais diferenciados (OLIVEIRA, 2008, p. 87).

Ainda segundo Margarida Maria Dias de Oliveira (2008), um dos desafios existentes na formação do professor de História reside na forma inócua como boa parte das experiências são vivenciadas no espaço da formação inicial. Para ela, não devemos esperar resultados propositivos quando uma parte significativa das atividades realizadas nos semestres iniciais se resumem a um "comportamento passivo" - para usar como empréstimo as palavras da autora - de assistir aulas e/ou reproduzir ideias prontas. Nas palavras de Oliveira: 
[...] ocorre apenas a reprodução de um discurso muito sofisticado da produção historiográfica contemporânea sobre a inviabilidade de busca de verdade, da escrita da História, como representação, da intencionalidade das fontes, das armadilhas da memória social, forjando uma 'formação' que não prepara o profissional de História para atuar na docência nem na pesquisa. (OLIVEIRA, 2008, p. 87).

O pouco interesse destinado pelos docentes (que atuam na formação de outros docentes) e pelos departamentos de História às relações que envolvem o ensino da História entra em rota de colisão com a constatação de que o ensino é o campo profissional da grande maioria dos licenciados em História no Brasil. Nas palavras da professora e historiadora Claudia Ricci (2015, p. I 19), “[...] essa postura de setores da universidade parece desconsiderar o fato de que a esmagadora maioria dos formandos em História das diferentes universidades brasileiras, públicas e privadas, tem o ensino como seu campo de trabalho".

A ciência que forma o historiador é a mesma que forma o professor de História. Os fundamentos epistemológicos da ciência histórica precisam, portanto, inserir em seu quinhão de interesse as reflexões que problematizam o ensino de sua área. Esse argumento se sustenta à medida que a maioria dos profissionais formada nessa área irá desempenhar a prática docente. São professores(as) que irão ensinar a História escolar a milhares de jovens. Portanto, é necessário que essa ciência capacite seus(suas) profissionais, colocando o ensino como objeto de interesse dentro da "área" que reflete seus fundamentos epistemológicos, ao invés de separar em fatias, definindo qual componente deve se encarregar do debate sobre o ensino de História.

\section{Considerações finais}

Em 2020, foi regularizada a profissão de historiador(a). Resultante de muitos anos de lutas, envolvendo diferentes professores e professoras de distintas instituições de ensino no Brasil e diferentes gestões da ANPUH. Essa ciência tem sido objeto de disputas políticas que resultaram em ataques aos seus praticantes na tentativa de silenciar as reflexões promovidas pelos(as) profissionais que nela atuam.

Esses ataques já provocaram a retirada do ensino de História do ensino médio. Também se desdobraram na construção de um projeto curricular comum por meio do qual foi instituído um ensino estruturado no modelo quadripartite europeu. As referências europeias que, inclusive, fizeram-se presentes nas citações publicadas nas postagens analisadas neste texto.

Os posts circulados nos perfis do Instagram, que serviram de indícios para analisar algumas imagens acerca da História e do(a) historiador(a), podem ser apropriados como uma síntese das representações que são atribuídas à própria História. Dito de outra maneira, trata-se de um conjunto de representações que mostram partes da face de uma ciência europeia, fundada por homens brancos

Olhar de professor, Ponta Grossa, v. 24, p. I-19, e-17095.042, 2021.

Disponível em <https://revistas2.uepg.br/index.php/olhardeprofessor> 
“Likes" para a história no Instagram: algumas questões sobre história, ensino e representação

que ainda continuam sendo as referências predominantes de lugar de saber/poder. Aquelas postagens fragmentárias e esparsas, resultantes das leituras interpretativas das pessoas que as construíram, sinalizam vestígios de como nossa ciência tem enfrentado o debate sobre o ensino de sua própria área: reservando um lugar de pouca expressividade dentro de sua oficina.

Enquanto nós - professores(as)/historiadores(as) formadores(as) de professores(as) continuarmos a manter o debate sobre o ensino e a formação docente em um lugar de pouca visibilidade, não estaremos contribuindo para vencer os desafios que envolvem, na atualidade, o ensino de História. Se continuarmos formando professores(as) com as matrizes curriculares do século XIX, teremos menos possibilidades de ressignificar o ensino de História na Educação Básica e, menos ainda, de mobilizar os(as) estudantes, despertando neles(as) o gosto e o interesse pela História. A História que forma seus(suas) professores(as), predominantemente por meio de uma concepção de tempo cronológico e linear, continua sendo atrelada a um passado distante e frio, sem vínculos com a vida cotidiana das pessoas que não são historiadores(as). Está mais do que na hora de pensar sobre as imagens que podemos oferecer para que a História desperte os links políticos sociais e culturais necessários a sua inserção na vida cotidiana das pessoas que não vivem no castelo em que se transformou a ciência histórica.

\section{Referências}

CAIMI, F. E. O que precisa saber um professor de história? Revista História \& Ensino, Londrina, v. 2I, n. 2, jul/dez. 20I5, p. 105-124. Disponível em: http://www.uel.br/revistas/uel/index.php/histensino/article/viewFile/23853/I774 I

CARVALHO, B. L. P. de. Faça aqui o seu login: os historiadores, os computadores e as redes sociais online. Revista História Hoje, São Paulo, v. 3, n. 5, p. I65-188, jan/jun, 20|4. Disponível em: https://doi.org//0.20949/rhhj.v3i5.126

CAVALCANTI, E. O que deve aprender o professor de História? Reflexões sobre aprendizagem, ensino e formação docente. Revista Roteiro, Joaçaba, SC, v. 45, p. I-24, jan/dez. 2020. Disponível em: https://doi.org/10.18593/r.v45i0.21829

CAVALCANTI, E. Ensino de História, livro didático e formação docente de professores de História no Brasil. Revista Enseñanza de las Ciencias Sociales, Barcelona, v. 18, p. 49-6I, jul/dez. 2019. Disponível em: https://www.raco.cat/index.php/EnsenanzaCS/article/view/363102

CAVALCANTI, E. A história encastelada e o ensino encurralado: reflexões sobre a formação docente dos professores de história. Revista Educar em Revista, Curitiba, v. 34, n. 72, p. 249 267, nov/dez. 2018. Disponível em: https://doi.org/I0.1590/0104-4060.60 I I I

CHARTIER, R. Formas e sentidos. Cultura escrita: entre distinção e apropriação. Campinas, SP: Mercado de Letras, 2003.

Olhar de professor, Ponta Grossa, v. 24, p. I-19, e-17095.042, 2021.

Disponível em <https://revistas2.uepg.br/index.php/olhardeprofessor> 
CHARTIER, R. Defesa e ilustração da noção de representação. Fronteiras, Dourados, MS, v. I3, n. 24, p. 15-29, jul./dez. 20I I. Disponível em:

https://ojs.ufgd.edu.br/index.php/FRONTEIRAS/article/view/I598

COELHO, M. C.; COELHO, W. N. B. As licenciaturas em História e a lei 10.639/03-percursos de formação para o trato com a diferença? Educação em Revista, Belo Horizonte, v. 34, e 192224, p. I-39, jul. 20 I8. Disponível em: https://www.scielo.br/pdf/edur/v34/I 982-662 I-edur-34-e l 92224.pdf

DULCI, T. M. S.; QUEIROJA JUNIOR, T. M. de. "Professores-youtubers": análise de três canais do YouTube voltados para o ensino de história. Revista Escritas do Tempo, Marabá, PA, vol. I, n. I, p. 04-29, mar/junmês(es). 2019. Disponível em:

https://periodicos.unifesspa.edu.br/index.php/escritasdotempo/article/view/4I0

FERREIRA, M. de M. O ensino de História, a formação de professores e a Pós-Graduação. Revista Anos 90, Porto Alegre, RS, v. 23, n. 44, p. $21-49$, dez. 2016. Disponível em: https://seer.ufrgs.br/anos90/article/view/68383

FERREIRA, M. de M.; FRANCO, R. Desafios do ensino de História. Estudos Históricos, Rio de Janeiro, RJ, v. 2I, n. 4I, p. 79-93, jul. 2008. Disponível em:

http://bibliotecadigital.fgv.br/ojs/index.php/reh/article/view/I 295

PACHECO, R. de A.; ROCHA, H. Quando o ensino de História vira tema de pesquisa: o ensino de História na Pós-Graduação em História. Revista Anos 90, Porto Alegre, RS, v. 23, n. 44, p. 5I-83, dez. 2016. Disponível em: https://seer.ufrgs.br/anos90/article/view/65880

OLIVEIRA, M. M. D de. O mundo da informação e os novos espaços para o ensino de história. In: OLIVEIRA, M. D. de; CAINELLI, M. R.; OLIVEIRA, A. F. B. de. Ensino de História: múltiplos ensinos em múltiplos espaços. Natal: Ed. UFRN, p. 85-93, 2008.

RICCI, C. S. Historiador e/ou professor de história: a formação nos cursos de graduação de História. Revista História Hoje, São Paulo, v. 4, n. 7, p. 107-135, jan/jul. 2015. Disponível em: https://rhhj.anpuh.org/RHHJ/article/view/I78

RÜSEN, J. Teoria da história: uma teoria da história como ciência. Curitiba: Editora da UFPR, 2015.

Recebido em: 08 de novembro de 2020.

Versão corrigida recebida em: 04 de fevereiro de 2021

Aceito em: II de fevereiro de 202I.

Publicado online em: 08 de maio de 2021.

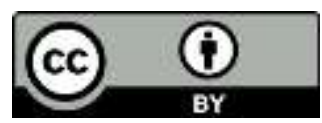

Olhar de professor, Ponta Grossa, v. 24, p. I-19, e-17095.042, 2021.

Disponível em <https://revistas2.uepg.br/index.php/olhardeprofessor> 